\title{
THE INTERNATIONAL LEGAL OBLIGATION TO TEACH WORLDISM IN U.S. CLASSROOMS
}

\author{
Scott Pasternack
}

I. INTRODUCTION

II. Why MUST THE UNITED States TEACH WORLDISM?
A. The Obligation in U.N. and OAS Resolutions and Declarations
B. The Obligation in Treaties

III. WHY START TEACHING WORLDISM AT THE PRIMARY AND SECONDARY SCHOOL LEVEL?
A. U.S. Research in Support of Primary and Secondary School Teaching
B. The Status Quo in the Absence of Primary and Secondary School Teaching
1. The Judiciary
2. The Legislature
3. The Executive

IV. What CHANGES TO U.S. EDUCATION LAWS NEED TO OCCUR?

V. CONCLUSION

\section{INTRODUCTION}

In the 1997 State of the Union address, United States President Bill Clinton set forth his seven priorities in education' that have helped to inspire passage of new curriculum statutes from legislatures and completion of new curriculum frameworks from education departments ${ }^{2}$ in U.S. states throughout the country. However, while encouraging a greater understanding and appreciation of the world through developments such as Internet $2000^{3}$ and multiculturalism, both the President and the U.S. states omit an important foundational element: the history, structure, and laws of international and

* Associate, Orrick, Herrington \& Sutcliffe LLP. Former law clerk to the Honorable Jacob Mishler, U.S. District Judge, Eastern District of New York. J.D., 1995, New York University School of Law. A.B., magna cum laude, 1991, College of William and Mary. The author wishes to thank Kerstin Stanley for her support through the drafting and editing process. Priorities].

1. See President's \& Secretary's Priorities <http://www.ed.gov/inits.html > [hereinafter

2. See, e.g., California Primary Schools <http://www.cde.ca.gov/cilbranch/eltdiv/ 98hssadoption.htm> for California.

3. "Every classroom will be connected to the Internet by the year 2000 and all students will be technologically literate." Initiative 6. See Priorities, supra note 1. 
regional institutions (what I hereafter term "worldism"). ${ }^{4}$

Legislative mandates to teach worldism in U.S. schools are long overdue. The United Nations General Assembly ("General Assembly" or "G.A.") has called continually for nations that are members in the organization ("Member States") to "study the possibility of introducing topics of international law in the curricula of schools at primary and secondary levels." Both the General Assembly and the United Nations Economic and Social Council ("ECOSOC") recommend that Member States "take measures ... to encourage the teaching of the United Nations Charter and the purposes and principles, the structure, background and activities of the United Nations in the schools and institutes of higher learning of their countries, with particular emphasis on such instruction in elementary and secondary schools." Although some U.S. state social studies frameworks include

4. Such a course would act as an umbrella covering many topics in addition to the basic organization and operations of the United Nations, Organization of American States and other international and regional institutions. For example, on the topic of international human rights, a common subject currently covered in many classrooms, the "history" component of worldism would include the history of human rights bodies like the United Nations ("U.N.") Commission on Human Rights; the "structure" component of worldism would include the structure of current human rights bodies like the U.N. Commissioner on Human Rights; and the "law" component of worldism would include aspects of human rights law such as the Universal Declaration on Human Rights, treaties, and worldwide human rights struggles and legal efforts.

5. The General Assembly has passed four resolutions during the 1990-1999 United Nations Decade of Intemational Law declared in G.A. Resolution 44/23 that each include this provision: G.A. Res. 45/40, Annex (Programme for the activities to be commenced during the first term (1990-1992) of the United Nations Decade of International Law), Part IV, para. 2 (<gopher://gopher.un.org:70/00/ga/recs/45/40>(visited Dec. 1, 1998)); G.A. Res. 47/32, Annex (Programme for the activities to be commenced during the second term (1993-1994) of the United Nations Decade of International Law), Part IV, para. 2 (<gopher://gopher.un.org: 70/00/ga/recs/47/32> (visited Dec. 1, 1998)); G.A. Res. 49/50, Annex (Programme for the activities for the third term (1995-1996) of the United Nations Decade of International Law), Part IV, para. 2 (<gopher://gopher.un.org:70/00/ga/recs/49/50> (visited Dec. 1, 1998)); G.A. Res. 51/157, Annex (Programme for the activities to be commenced for the final term (19971999) of the United Nations Decade of International Law), Part IV, para. 15 (<gopher://gopher.un.org/00/ga/recs/51/RES51-EN.157> (visited Dec. 1, 1998)). These four resolutions inspired the General Assembly to include a similar provision on teaching international law in primary and secondary curricula in its biannual resolution on the United Nations Program of Assistance in the Teaching, Study and Dissemination and Wider Appreciation of International Law ("U.N. Program of Assistance"). Compare G.A. Res. 40/66, 40 U.N. GAOR, Supp. 53 at 303, para. 8, U.N. Doc. A/40/53 (1985) (existing before the passage of any U.N. Decade resolution), with G.A. Res. 52/152, U.N. GAOR, 52nd Sess., Supp. 49 at 369, para. 13, U.N. Doc. A/52/49 (1997) (existing after the passage of the first term U.N. Decade resolution; passage of the next resolution on the subject will occur in the 54th Session.). For a list of U.N. Program of Assistance resolutions from the original (G.A. Res. 2099(XX)) until 1993 (G.A. Res. 48/29), see Report of the Secretary General, U.N. GAOR, 50th Sess., Annexes at Agenda Item 39 at note 1, U.N. Doc. A50/726 (1995).

6. G.A. Res. 137(II), 2 U.N. GAOR, Resolutions at 45, U.N. Doc A519 (1947). Although the General Assembly initiated the effort to teach about the United Nations, it transferred the program to ECOSOC in that Resolution. ECOSOC then expanded the scope to 
aspects of the United Nations, multilateralism, and international human rights in world history or post-Cold War studies courses, ${ }^{7}$ no U.S. state legislature has amended its social studies curriculum statutes to mandate worldism together with already required federal, state, and local civics classes. ${ }^{8}$

So many legitimate activities in this world-e.g., economic, military, technological, medical, energy, law enforcement-depend on the joint effort of two or more nations rather than the work of just one: such bilateral and multilateral approaches create greater economies of scale and a better and safer quality of life for humanity. That nations cling to their risk-averse sense of sovereignty in the name of security only serves to undermine this process. However, since the end of World War II when the United States profited greatly from Europe's misery, the United States has maintained, and during the Cold War fought to preserve, a hegemonic order for itself. The mandated components of federal, state, and local civics classes in U.S. primary and secondary schools ensure that U.S. citizens accept this hegemony without question (there are few people in the United States who could imagine a better form of government). ${ }^{9}$ At the dawn of a new millenium, such insularity hinders progress and truly risks downfall. If the United States intends to avoid declining like other great nations in history, it needs to embrace the realities of regional and international institutions - their history, their structure, and their laws-instead of avoiding them. The United States must introduce these concepts fully into the popular way of thinking.

Just as required federal, state, and local civics classes implant children and adolescents with the seeds of patriotism that flower when they reach adulthood into a basic appreciation and loyalty for the United States as a civil

include the specialized agencies of the United Nations and to require Member States to report to the Secretary-General and the United Nations Education, Scientific and Cultural Organization (UNESCO) on their progress. See infra note 19.

7. See,e.g., <http://www.doe.mass.edu/edreform/standards> (pertaining to Massachusetts); <http://www.cde.ca.gov/secondary> (pertaining to California); <http://www. state.vt.us/educ/stand/h\%ss.htm> (pertaining to Vermont); <http://www.edneb.org/IPS/Issu/SS/ SocSStnd.html> (pertaining to Nebraska).

8. See, e.g., CAL. EDUC. CODE $\$ \S 51210,51220,51226.3$ (West 1998); FL. STAT. ANN. \$233.061 (West 1999); MASS. GEN. LAWS ANN., c. 71 \& 2 (West 1998); NEB. REV. STAT. § 79724 (1996); N.M. STAT. ANN. § 22-13-11 (Michie 1998); VT. STAT. ANN. tit. 16, § 906(b)(2) (1998). See also infra note 12.

9. Consider this provision in the Nebraska education laws: "In at least two grades of every high school, at least three periods per week shall be devoted to the teaching of civics, during which courses specific attention shall be given to the following matters: ... (b) The benefits and advantages of our form of government and the dangers and fallacies of Nazism, Communism, and similar ideologies[.]" NEB. REV.STAT. \$ 79-724(5)(1996). In addition, most U.S. state curriculum statutes explicitly require class time devoted to the study of the U.S. flag, the fostering of patriotism, or both. See, e.g., CONN. GEN. STAT. ANN. $\S 10-18$ (West 1998); IND. CODE ANN. $\S 20-10.1-4-4$ (1998); WASH. REV. CODE ANN. $\S 28 A .230 .140$ and $\S$ 28A.230.150 (West 1998). 
society, so too will mandated worldism classes at the primary and secondary school levels cultivate in the U.S. population a similar respect for the history, structure, and laws of international and regional institutions. Recent scholarship on approaches in teaching about international law and its institutions focuses on supplementing undergraduate government curricula ${ }^{10}$ or law school curricula" but not on changing primary and secondary school curricula. ${ }^{12}$ The freshman international relations course taken at age eighteen is simply too little too late; imagine how ingrained the cherishing of the history, interpretation, and text of the U.S. Constitution might be if U.S. citizens were not required to learn about such elements until they attended college.

This Article poses and responds to three significant questions in order to demonstrate the importance of revising primary and secondary school social studies curricula to include mandatory worldism classes. First, why must the United States teach worldism? Second, if the United States must teach worldism, why start the teaching at the primary and secondary school level? Third, if the United States must start teaching worldism at the primary and secondary school level, what changes need to occur in U.S. education laws to implement this mandate?

10. See Basil Karp, Teaching the Global Perspective in American National Government: A Selected Resource Guide, 25 PS: POLITICAL SCIENCE AND POLITICS 703 (1992).

11. See John A. Barrett, Jr., International Legal Education in U.S. Law Schools: Plenty of Offerings, but Too Few Students, 31 INT'L LAW. 845 (1997); Symposium on the Teaching of International Criminal Law, 1 TOURO J. TRANSNAT'L L. 129 (1988); Teaching International Relations and International Organizations in International Law Courses: Constructing the State-of-the-Art International Law Course, 87 AM. SOC. INT'L. L. PrOC. 398 (1993).

12. According to a joint U.N. Secretary-General and UNESCO summary of a U.S. Department of Education report entitled Teaching about the United Nations in the United States of America, 1960-63, "[ $t]$ he opinion of many American educators is that much more can be done to strengthen and improve teaching about the international scene. More and better school materials need to be prepared, teachers should have improved, in-service courses, and more effective methods of teaching need to be employed, including the use of educational television." Report of the Secretary-General of the United Nations and the Director General of the United Nations Educational, Scientific and Cultural Organization on the Teachingof the Purposes and Principles, the Structure and Activities of the United Nations and the Specialized Agencies in the Schools and Other Education Institutions of Members States, in U.N. ESCOR, 37th Sess., Annex 33 at 66, U.N. Doc. E/3875 and Add. 1-3 (1964).

Although the U.S. and U.N. reports are more than 30 years old, the most to have occurred since the 1960 s is the incorporation of teaching and educational materials into already existing curricula. See, e.g., Helena Benitez, Globalization in U.S. History: Six Strategies, 58 SoC. EDUC. 142 (1994); Betty A. Reardon, Human Rights and Values Education: Using the International Standards, 58 Soc. Educ. 427 (1994); Felisha Tibbitts, On Human Dignity: The Need for Human Rights Education, 60 Soc. EDUc. 428 (1996); Ron Wheeler, Post-Cold War Social Studies, 58 Soc. EDUC. 287 (1994). See also 58 Soc. EDuc. (1996) (devoting entire issue to the U.N.'s fiftieth anniversary); 56 Soc. EDuc. (1992) (devoting entire issue to the Convention on the Rights of the Child). These articles neither discuss lobbying for legislative change nor mandating the teaching of these subjects. 


\section{WHY MUST THE UNITED STATES TEACH WORLDISM?}

International law and regional law morally and legally obligate the United States to teach worldism. The Charter of the United Nations ("U.N. Charter") mandates "promoting international cooperation in the political field and encouraging the progressive development of international law ...." The U.N. Charter legally binds the United States to help fulfill this obligation. ${ }^{14}$ Similarly, at the regional level, the Charter of the Organization of American States ("OAS Charter") ${ }^{15}$ proclaims generally that "[i]nternational law is the standard of conduct of States in their reciprocal relations" 16 and calls on one of its organs "to promote the progressive development ... of international law[.]"17 Like the U.N. Charter, the OAS Charter legally binds the United States.

\section{A. The Obligation in U.N. and OAS Resolutions and Declarations}

Following the U.N. Charter's mandate, the General Assembly and ECOSOC have, since inception, passed numerous resolutions requiring, recommending, and inviting Member States to teach components of worldism. These resolutions bind the United States morally as a voting member of each body. Some of these resolutions focus on teaching about international institutions, one of worldism's components, in primary and secondary school. In its initial resolution on the Teaching of the Purposes and Principles, the Structure and Activities of the United Nations in the Schools of Member States, the General Assembly states:

Considering that knowledge and understanding of the aims and activities of the United Nations are essential in promoting and assuring general interest and popular support

13. ChARTER OF THE UNITED NATIONS (as amended) [hereinafter U.N. CHARTER], at art. 13, para. 1, reprinted in INTERNATIONAL LAW: SELECTED DOCUMENTS 1, 5 (Barty E. Carter \& Phillip R. Trimble eds., 1991) (latest amendments at 24 U.S.T. 2225) [hereinafter SELECTED DOCUMENTS].

14. The United States signed the U.N. Charter in San Francisco on June 26, 1945, and became a member of the organization at that time. As a self-executing treaty to which the United States is party, the U.N. Charter provisions legally binds the United States because "all Treaties made, or which shall be made, under the Authority of the United States, shall be the supreme Law of the Land; and the Judges in every State shall be bound thereby, any Thing in the Constitution or Laws of any State to the Contrary notwithstanding." U.S. CONST., art. VI, $\S 2$.

15. Charter of the Organization of American States, 2 U.S.T. 2394; amended effective 1970, 21 U.S.T. 607, T.I.A.S. No. 6847, reprinted in SELECTED DOCUMENTS, supra note 13, at 237 [hereinafter OAS CHARTER].

16. Id. art. 3(a), reprinted in SELECTED DOCUMENTS, supra note 13, at 238.

17. Id. art. 105, reprinted in SELECTED DOCUMENTS, supra note 13, at 256. 


\section{of its work;}

Recommends to all Member Governments that they take measures at the earliest possible date to encourage the teaching of the United Nations Charter and the purposes and principles, the structure, background and activities of the United Nations in the schools and institutes of higher learning of their countries, with particular emphasis on such instruction in elementary and secondary schools[.] ${ }^{18}$

ECOSOC succeeded the General Assembly in continuing this effort and passed its first resolution on the subject a year later:

Realizing that, for the successful functioning of the United Nations and its specialized agencies, it is essential that their purposes, principles and activities be widely known in order to develop among all the peoples of the world a realization of the benefits which can be derived from international organization, and of the proper ways of utilizing the existing instruments of international collaboration;

Recommends that Member States make full use of the information and advice which the United Nations and the United Nations Educational, Scientific and Cultural Organization can provide on the subject and intensify their efforts to promote in their respective territories the teaching of the purposes, principles, structure and activities of the United Nations and its specialized agencies. ${ }^{19}$

Other United Nations resolutions focus on teaching about international law, another of worldism's components, and have grown to include specific reference to primary and secondary schools. Initially, the General Assembly writes:

Considering that one of the most effective means of furthering the development of international law consists in promoting public interest in this subject and using the media of education and publicity to familiarize the peoples with the principles and rules that govern international relations;

Considering that greater knowledge of and fuller 
information on the aims, purposes and structure of the United Nations constitute another positive method of assisting the development of international law, of which the United Nations is the main instrument ...

Resolves to request the Government of Member States:

1. To take appropriate measures to extend the teaching of international law in all its phases, including its development and codification, in the universities and higher educational institutions of each country that are under government control or over which Governments have some influence or to initiate such teaching where it is not yet provided;

2. To promote similar teaching regarding the aims, purposes, structure and operation of the United Nations in conjunction with paragraph 1 above and in accordance with resolution 137(II) adopted by the General Assembly on 17 November 1947, on the teaching of the purposes and principles, the structure and activities of the United Nations in the schools of Member States[.] ${ }^{20}$

This resolution evolved into the United Nations Program of Assistance in the Teaching, Study, Dissemination and Wider Appreciation of International Law. ${ }^{21}$ By the 1990s, the General Assembly's encouragement in these resolutions to teach international law explicitly referred to primary and secondary schools. ${ }^{22}$

The repeated passage from 1947 to the present of these General Assembly and ECOSOC resolutions ${ }^{23}$ not only morally binds the United States but also demonstrates state practice and perhaps even sufficient opinio juris sive necessitatis to make the obligations legally binding on the United States as customary international law. ${ }^{24}$ Similar OAS resolutions passed pursuant to

20. G.A. Res. 176(II), 2 U.N.GAOR, Resolutions at 110-11, U.N. Doc. A/519 (1947).

21. See supra note 5.

22. See supra note 5.

23. Regarding later action on teaching about international institutions, see ECOSOC Res. 748 (XXIX), ESCOR 29th Session, Resolutions, Supp. No. 1 at 4-5, U.N. Doc. E/3373 (1960); ECOSOC Decision No. 6, ESCOR 48th Session, Resolutions and Decisions, Supp. No. 1A at 20 (1970). Regarding later action on teaching about international law, see supra note 5.

24. See Article 38(1)(b) of the Statute of the International Court of Justice, June 26, 1945 , 59 Stat. 1055, T.S. No. 993, Bevans 1179 ("The Court, whose function is to decide in accordance with international law such disputes as are submitted to it, shall apply: . . . (b) international custom, as evidence of a general practice accepted as law."); RESTATEMENT (THIRD) OF THE FOREIGN RELATIONS LAW OF THE UNITED STATES $\S 102(2) \& \& 102 \mathrm{cmts}$. b \& c, reporters note 2.

Customary international law is one of the two primary sources of international law, the other being international agreements such as treaties. See id. $\S 102(1) \& \mathrm{cmt}$. l. "Customary 
the OAS Charter mandates discussed above emphasize the importance of teaching about international and regional law. ${ }^{25}$

The legislative history of the above-mentioned U.N. resolutions points to a central role that the United States played in drafting the texts and upholding the message. For example, on G.A. Resolution 137(II), Eleanor Roosevelt, representing the United States in the General Assembly's Third Committee, announced U.S. support specifically for the first preambulary paragraph and the first main paragraph quoted above. ${ }^{26}$ In the General Assembly Plenary Meetings, Mrs. Roosevelt actively participated by forging a compromise between the Third Committee draft and a Cuban amendment to create the adopted version of G.A. Resolution 137(II). ${ }^{27}$ Meanwhile, in ECOSOC, the United States spoke of universal recognition of the importance of teaching about the United Nations and its specialized agencies, ${ }^{28}$ praised the Secretary General for his efforts toward that end, ${ }^{29}$ and stated that " $[t]$ eaching about the United Nations should be a continuous programme and ought to be interwoven throughout the student's curriculum so that children might know what repercussions the decisions taken by the United Nations ha[ve] on their daily life." 30

In addition to these United Nations resolutions, Article 26(2) of the Universal Declaration of Human Rights ("UDHR") proclaims that education "shall promote understanding, tolerance and friendship among all nations, racial or religious groups, and shall further the activities of the United Nations for the maintenance of peace." ${ }^{31}$ The United States again played an active role in drafting this language and supporting its intent. A joint U.S.-Mexican amendment added to Article 26(2) the phrase "shall further the activities of

international law results from a general and consistent practice of states followed by them from a sense of legal obligation." Id. § 102(2). Generally speaking, nation-states who are part of the international system are bound to any practice that ripens into customary international law unless they consistently indicate their dissent and the practice at issue is not a peremptory norm. See id. $\$ 102 \mathrm{cmts}$. a, d and $\mathrm{k} \&$ reporters note 2.

25. See generally AG/RES. 1471 (XXVII-O/97)(1997 7th plen. sess.) (adopting the Inter-American Program for the Development of International Law); Declaration of Panama on the Inter-American Contribution to the Development and Codification of International Law, AG/DEC. 12 (XXVI-O/96) (emphasizing the importance of instruction about international and regional law).

26. See U.N. GAOR, 3d Comm., 2d Sess., $81 \mathrm{st} \mathrm{mtg.} \mathrm{at} \mathrm{217,} \mathrm{U.N.} \mathrm{Doc.} \mathrm{AV.3/SR.81}$ (1947). Lebanon's draft of the first main paragraph can be found at 2 U.N. GAOR, Annex 13a at 267, U.N. Doc. A/C.3/190 (1947). China's draft of the first preambulary paragraph can be found at 2 U.N. GAOR, Annex 13b at 267-68, U.N. Doc. A/C.3/195 (1947).

27. See U.N. GAOR, 2d Sess., 117 th plen. mtg. at 1036-37, U.N. Doc. A/SR. 117(1947).

28. U.N. ESCOR, 7th Sess., 198th mtg. at 367, U.N. Doc. E/SR.198 (1948).

29. U.N. ESCOR, 8th Sess., 233d mtg. at 69, U.N. Doc. E/SR.233 (1948).

30. Id.

31. Universal Declaration of Human Rights, December 10, 1948, G.A. Res. 217 (III 1948), at art. 26(2), reprinted in SELECTED DOCUMENTS, supra note 13, at 352, 356. 
the United Nations for the maintenance of peace." 32 The drafters intended this language to incorporate and more widely disseminate the principles of G.A. Resolution 137 (II). ${ }^{33}$ The combination of the implication in Article 26(2) and the explication in G.A. Resolution 137(II) strengthens the obligation on the part of Member States to teach in schools about the purposes, principles, structure, and activities of the United Nations and its specialized agencies. ${ }^{34}$ Consequently, the United States, as a drafter of the portion of Article 26(2) promoting awareness of worldism, as a party to the Universal Declaration on Human Rights, and as a member of the General Assembly, is bound to meet this obligation.

\section{B. The Obligation in Treaties}

Apart from U.N. resolutions and declarations, the general right to education in various multilateral human rights conventions with which the

32. See 3 U.N. GAOR, 3d comm., Annexes to Summ. Records at 84 , U.N. Doc. A/C.3/356 (1948) (joint U.S.-Mex. amendment). See also 3 U.N. GAOR, 3 d comm., 147 th mtg. at 596, U.N. Doc. A/C.3/SR.147 (1948-49)(documenting the United States introduction of the joint amendment at the 147th meeting of the Third Committee); 3 U.N. GAOR, 3d Comm., 148th mtg. at 604, U.N. Doc. A/C.3/SR.1 48 (1948-49) (documenting the Third Committee's adoption of the amendment at the next meeting). The World Jewish Congress ("WJC") proposed the original text for this provision during a session of the Working Group on the Declaration on Human Rights ("Working Group") which met throughout the second session of ECOSOC's Commission on Human Rights ("Commission"). See Report of the Working Group on the Declaration on Human Rights, U.N. ESCOR, Comm'n on Human Rights, 2d Sess. at 14, U.N. Doc. E/CN.4/57 (1947). Then in its third session, the Commission subsequently amended both the WJC text and the Working Group draft before forwarding to the plenary session of ECOSOC the following draft provision: "Education shall be directed to the full development of the human personality, to the strengthening of respect for human rights and fundamental freedoms and to the promotion of international goodwill[,] and to the combatting of the spirit of intolerance and hatred against the nations or racial or religious groups." U.N. ESCOR, Comm'n on Hurnan Rights, 3d Sess., 69th mtg. at 9, U.N. Doc. E/CN.4/SR.69 (1948). ECOSOC referred this provision, along with the rest of the draft Declaration on Human Rights, to the General Assembly who delegated it to its Third Committee. There the United States and Mexico introduced their joint amendment which became part of the final text of the Universal Declaration on Human Rights. See supra note 31.

33. See G.A. Res. 137(II), 3 U.N. GAOR, 3d Comm., 146th mtg. at 582-83, U.N. Doc. A/C.3/SR. 146 (1948-49) (noting that at this meeting the Mexican delegate stated, regarding the proposal for adding the instant United Nations language to Article 26(2), that "[i]f such a provision were included in the declaration, [then G.A. Res. 137(II)] would obtain a far wider hearing."

34. See RESTATEMENT (THIRD), supra note $24, \S 103 \mathrm{cmt}$. c \& reporters note 2 (stating that "[r]esolutions by a principal organ of an organization interpreting the charter of the organization [i.e., G.A. Resolution 137(II) interpreting Article 13 of the U.N. Charter] may be entitled to greater weight. ... [and d]eclarations interpreting a charter [i.e.,Univeral Declaration of Human Rights interpreting Articles 55 and 56 of the U.N. Charter] are entitled to considerable weight if they are unanimous or nearly unanimous and have the support of all the principal members." (emphasis added)). 
United States either should or must comply often includes a content component that implicitly calls for worldism in school curriculum. Article 13(1) of the International Covenant on Economic, Social and Cultural Rights ("ICESCR") states that parties "agree that education shall enable all persons to participate effectively in a free society, promote understanding, tolerance and friendship among all nations and all racial, ethnic or religious groups, and further the activities of the United Nations for the maintenance of peace." 35 Article 29(1)(b) of the Convention on the Rights of the Child ("CRC") directs education to include "[t]he development of respect for human rights and fundamental freedoms, and for the principles enshrined in the Charter of the United Nations." ${ }^{36}$ Article 5(1)(a) of the UNESCO Convention Against Discrimination in Education ("CADE") states that "[e]ducation shall be directed to ... the strengthening of respect for human rights and fundamental freedoms; it shall promote understanding, tolerance and friendship among all nations, racial or religious groups, and shall further the activities of the United Nations for the maintenance of peace." 37

Although only the U.N. Charter and the OAS Charter directly bind the United States, international law requires nations to comply with, if not specifically obey, the education provision of these other documents. For the instruments that the United States has signed but not ratified (i.e., ICESCR and (RC), Article 18 of the Vienna Convention on the Law of Treaties ${ }^{38}$ obligates this country not to act contrary to the object and purpose of the provisions of those conventions. ${ }^{39}$ For the instruments to which the United States is not a signatory (i.e., CADE), "the standards contained [therein] ... are either part of customary international law or are the most important

35. International Covenant on Economic, Social and Cultural Rights, Dec. 16, 1966, art. 13, para. 1, 993 U.N.T.S. 3, reprinted in SELECTED DOCUMENTS, supra note 13, at 376, 380.

36. Convention on the Rights of the Child, November 20, 1989, art. 29(1)(b), 28 I.L.M. 1448, 1468 (1989), reprinted in BASIC DOCUMENTS ON HUMAN RIGHTS 193 (Ian Brownlie ed., 3d ed. 1991)[hereinafter BASIC DOCUMENTS].

37. December 14, 1960, art. 5(1)(a), 429 U.N.T.S. 93, reprinted in BASIC DOCUMENTS, supra note 36 , at $234,236$.

38. Vienna Convention on the Law of Treaties, May 23, 1969, art. 18, U.N. Doc. AVCONF. 39/27, reprinted in SELECTED DOCUMENTS, supra note 13, at $51,56$.

39. Despite the fact that the U.S. Senate has not yet ratified the Vienna Convention, the U.S. Department of State has said that "the Convention is already generally recognized as the authoritative guide to current treaty law and practice." RESTATEMENT (THIRD), supra note 24, at 145 (quoting S.Exec.Doc.L. 92d Cong., 1st sess. (1971) at 1). Furthermore, the U.S. Department of State regards particular Vienna Convention articles as codifying existing international law, and federal courts have treated particular provisions as authoritative. RESTATEMENT (THIRD), supra note 24, at 145, note 2 (citing various Digest of U.S. Practice in International Law pages and federal court cases). Thus, the United States has assented to being bound by the Vienna Convention just like any other customary international law or treaty law obligation. 
evidence of the content of customary international human rights law." ${ }^{30}$ Given these understandings, the spirit of international law demands mandatory teaching of worldism under U.S. education laws in state and federal statutes, regulations, and directives. Such teaching is best begun at the primary and secondary school level.

\section{WHY START TEACHING WORLDISM AT THE PRIMARY AND SECONDARY SCHOOL LEVEL?}

Changing federal and state education laws to provide for mandatory teaching of worldism at the primary and secondary school level will improve the attitude of citizens toward the legitimacy of international and regional organizations as governing bodies. In the United States, an underlying consensus among the citizenry that one should respect domestic laws and the institutions that create, implement, and interpret them allows for the expected and effective enforcement of penal codes and bargained-for agreements. However, most U.S. citizens lack an equal level of respect for international laws and the institutions that create, implement, and interpret them. Arguably, a key explanation for the difference in respect for domestic law and international law is that U.S. states require repeated primary and secondary school coursework in federal, state, and local civics in order to cultivate respect for the.U.S. Constitution and society's laws whereas no U.S. state requires primary and secondary school coursework in worldism which might instill a similar attitude toward international and regional laws.

\section{A. U.S. Research in Support of Primary and Secondary School Teaching}

A report ${ }^{41}$ from the U.S. National Commission for UNESCO at the U.S.

40. Kathryn Burke et al., Application of International Human Rights Law in State and Federal Courts, 18 TEX. INT'L. L. J. 291, 321 (1983). See Susan H. Bitensky, Theoretical Foundations for a Right to Education Under the U.S. Constitution: A Beginning to the End of the National Education Crisis, 86 Nw. U. L. REV. 550, 639 (1992); Stephen Knight, Proposition 187 and International Human Rights Law: Illegal Discrimination in the Right to Education, 19 Hastings INT'L. \& Comp. L. Rev. 183, 198 (1995); Connie de la Vega, Protecting Economic, Social and Cultural Rights, 15 WHITTIER L. REV. 471, 471-72 \& n. 59 (1994). At issue here is which, if not all, elements (i.e., non-discrimination, free for all, content of what is taught) that comprise an international human right to education has crystallized into a customary legal obligation and, therefore, binds the United States regardless of whether the United States has ratified particular instruments.

41. ThOMAS BUERGENTHAL \& JUDITH V. TORNEY, U.S. DEP'T OF STATE, INTERNATIONAL HUMAN RIGHTS AND INTERNATIONAL EDUCATION (1976) [hereinafter BUERGENTHAL \& TORNEY]. 
Department of State analyzing a 1974 UNESCO Recommendation ${ }^{42}$ strongly supports the position that worldism must be taught at the primary and secondary school level to have an effective impact. The authors of the report-Professors Thomas Buergenthal and Judith V. Torney-devote one chapter to "Major Research Findings Concerning Students' International Knowledge and Attitudes" ${ }^{43}$ in order, inter alia, to give greater meaning to the following principle from the UNESCO Recommendation:

In order to enable every person ... to promote international solidarity and co-operation, which are necessary in solving the world problems affecting the individuals' and the communities' life and exercise of fundamental rights and freedoms, the following objectives should be regarded as major guiding principles of educational policy:

(a) an international dimension and a global perspective in education at all levels and in all its forms;

(b) understanding and respect for all peoples, their cultures, civilizations, values and ways of life, including domestic ethnic cultures and cultures of other nations;

(c) awareness of the increasing global interdependence between peoples and nations;

(d) abilities to communicate with others;

(e) awareness not only of the right but also of the duties incumbent upon individuals, social groups and nations toward each other;

(f) understanding of the necessity for international solidarity and co-operation readiness on the part of the individual to participate in solving the problems of his community, his country and the world at

42. U.N.E.S.C.O. Recommendation Concerning Education for International Understanding, Co-operation and Peace and Education Relating to Human Rights and Fundamental Freedoms, 18 th Session of UNESCO, November 19, 1974 [hereinafter UNESCO Recommendation]. As a member of UNESCO at the time of the eighteenth session (October 17, 1974 to November 23, 1974), the United States helped draft the UNESCO Recommendation and became a party to it. "[A]s their name suggests, recommendations are non-obligatory statements of principles or norms which [UNESCO] recommends should be applied or implement by [its] Member States." BUERGENTHAL \& TORNEY, supra note 41, at 3. Thus, by a legislative or quasi-legislative act, the 1974 UNESCO Recommendation inviles but does not compel United States compliance with its provisions. See id. at 10-11.

43. See BUERGENTHAL \& TORNEY, supra note 41 , at 102-23. 
large. ${ }^{44}$

The authors begin the chapter by citing a then-recent education study from the National Council on Social Studies which drew the following conclusions:

VI. International learning begins early in life.

VII. International learning is cumulative ... what children learn at one age builds upon and is influenced by what they have previously learned.

VIII. The time of middle childhood (grades three through eight) is an important period in international learning.

IX. The beliefs, attitudes, values, and knowledge individuals develop about the world differ-each individual student brings his or her own particular configuration of orientations toward the world.

$\mathrm{X}$. The mass media, especially television and newspapers [and, today, the Internet], play an important role in children's international learning. ${ }^{45}$

From an analysis of similar research studies, the authors determine that:

[P]ositive national identity is established very early and forms part of the child's perspective for viewing the activity of other nations and of his own, as well as the future of international society. The period before the age of fourteen is especially important because the child's openness to

44. UNESCO Recommendation, supra note 42, Preamble, para. 7. At the time that UNESCO passed the recommendation, the United States was still a Member State. Therefore, pursuant to the preamble of the UNESCO Recommendation, the United States had a duty to take legislative or other steps to give effect to the above provision. Moreover, "[a]lthough [the United States] ha[s] no legal obligation to give effect to the provisions [such as this one] of a UNESCO recommendation, [it] is required by the UNESCO Constitution to bring the recommendation to the attention of those national agencies in [this] country that are empowered to regulate and act upon the subjects dealt with in the recommendation. . . ." Since the 1974 UNESCO Recommendation deals with diverse educational practices, policies and programs, the U.S. government would seem to be under an obligation to transmit copies of the instrument to all chief state school officers, to major private education organizations, to the U.S. Commissioner of Education and to the U.S. Congress. The subjects covered by the Recommendation fall within the general jurisdiction of the States of the Union because they concern education, but many related policies are today also governed by federal guidelines." BUERGENTHAL \& TORNEY, supra note 41, at 3. See also UNESCO Recommendation, supra note 42, Preamble, para. 8.

45. RICHARD C. REMY ET AL., INTERNATIONAL LEARNING AND INTERNATIONAL Education IN A GLOBal AGE 39-40 (1975). 
diversity in this period is more likely to foster positive international attitudes. Exaggerated support for his own national government . . . may curtail the child's positive orientations toward other nations [or, presumably, regional organizations and international organizations]. . . In the United States students tend to possess less knowledge about international than about national matters and to be less motivated to participate in discussion of international affairs outside the classroom than are the students of other countries.

Studies of attitudes and knowledge about the UN typically conclude that children perceive it as an organization which feeds the hungry and tries to make peace. The ideas of adolescents are somewhat more sophisticated....

Action to improve education must take place on all levels of instruction and in a variety of modes. An international or intercultural dimension should be an explicit and implicit part of classroom functioning. There appears to be no reason why the global perspective cannot be fostered through many subjects of study without detracting from the mastery of prescribed subject matter....

The UNESCO Recommendation has given the appropriate breadth of focus.... A new course here or a new extra-curricular project there will not even approximate the degree of understanding of other peoples of the world, their problems and aspirations which will be needed by presentday students to become well-balanced and socially effective adults. $^{46}$

Although the above report is more than twenty years old, the authors' conclusions are still timely, particularly since the importance of fostering international attitudes is arguably more urgent today than twenty years ago. Current education experts remain concerned: "While the need for global and international studies education is generally accepted, there is no agreement as to what it means, or how this need can be implemented in our nation's schools." 47 To provide an effective solution to this continual dilemma, our

46. BUERGENTHAL \& TORNEY, supra note 41 , at 122-23.

47. Andrew Smith, A Brief History of Pre-Collegiate Global and International Studies Education, in EDUCATION FOR AMERICA'S ROLE IN WORLD AFFAIRS 1, 17 (John Fonte \& Andre Ryerson eds., 1994). Cf. THE TEACHING OF CONTEMPORARY WORLD ISSUES (UNESCO \& World Confederation of Organizations of the Teaching Profession eds., 1986) (furnishing ideas from a number of educators from different countries addressing such major issues as peace, human rights, and international understanding and cooperation); Rudolf Pfeifer, Main Themes of the UNESCO Recommendation, in TEACHING FOR INTERNATIONAL UNDERSTANDING, PEACE 
federal government should encourage U.S. state legislatures to pass social studies curriculum statutes that mandate teaching worldism at the primary and secondary school level or, otherwise, accept the limitations of the status quo.

\section{B. The Status Quo in the Absence of Primary and Secondary School Teaching}

Failing to teach worldism at the primary and secondary school level and thereby depriving future generations of a better awareness of the history, structure, and laws of international and regional organizations will perpetuate a status quo among the current adult population that neither appreciates nor understands the benefits and efficiencies of greater U.S. participation in and respect for the organizations and the laws at the regional and global level. This status quo sanctions disregard for (and sometimes ignorance about) these organizations and laws by U.S. judicial, legislative, and executive branches of government in their public sector work, even while the private sector already recognizes these benefits and efficiencies to some degree. ${ }^{48}$

\section{The Judiciary}

Many federal and state courts either do not know how and when to refer to international law or consider it unimportant. Judicial opinions reflect more than a simple lack of understanding about international law (a deficiency which an introductory course taken by judges or their clerks in law school would have corrected). An attitude that legal sources outside the realm of the federal and state constitutions and statutes are secondary and unimportant law (if even law at all) combined with a deference to public policy permits a seeming lack of good sense in these courts' reasoning.

In United States $v$. Alvarez-Machain, ${ }^{49}$ Chief Justice Rehnquist demonstrated his lack of concern for international law when he opined, with a 6-3 majority, that the Supreme Court had personal jurisdiction over a defendant brought to the United States not pursuant to the procedure set forth

AND HUMAN RIGHTS 23-30 (Norman J. Graves et al. eds., 1984) (outlining the interrelationship between international efforts aimed at such areas as peace, discrimination, the environment, and education). A worldism course could cover thoroughly the subjects discussed in the latter two UNESCO publications. See supra note 4.

48. See Paul Beckett \& Christopher Rhoads, Deutsche Bank, Bankers Trust Formalize Deal, WALL ST. J., Nov. 30, 1998, at A4 (reporting on the largest foreign acquisition of a U.S. bank); Agis Salpukis, Continental Picks Air Canada Bid for a Merger to End Bankruptcy, N.Y. TIMES, Nov. 10 1992, at A1 (reporting on the Air Canada-Continental Airlines merger); Barrett Seaman and Ron Stodghill II, The Daimler-Chrysler Deal: Here Comes the Road Test, TIME, May 18, 1998, at 66 (discussing "the triumph of the global economy and the end of car companies as national emblems of industrial might.").

49. United States v. Alvarez-Machain, 504 U.S. 655 (1992). 
in the binding U.S.-Mexican extradition treaty but by means of forcible abduction undertaken in Mexico by U.S. federal agents. Many legal scholars have criticized the Court's reasoning in this case. ${ }^{50}$ First, when analyzing the text of the treaty, Rehnquist failed to apply or even consider Articles 31 to 33 of the Vienna Convention on the Law of Treaties ${ }^{\text {st }}$ concerning the jurisprudence of treaty interpretation, referring instead to standard domestic statutory interpretation. ${ }^{52}$ Second, the Court completely ignored customary international law ${ }^{53}$ when it concluded that forcible abduction by the United States was legally permissible because "[t]he Treaty says nothing about the obligations of the United States and Mexico to refrain from forcible abductions of people from the territory of the other nation, or the consequences under the Treaty if such an abduction occurs." 54 Absent a specific treaty provision, the Supreme Court should have referred to customary international law as the other primary source of law that governs activities between states. Had the Court looked to this source, it would have concluded easily, as did the dissent, ${ }^{55}$ that the United States' behavior violated customary international law: the United States used force against the territorial integrity of Mexico and, in the absence of consent from the foreign

50. See Michael J. Glennon, State-sponsored Abduction: A Comment on United States v. Alvarez-Machain, 86 AM. J. INT'L. L. 746 (1992); John Quigley, Our Men in Guadalajara and the Abduction of Suspects Abroad: A Comment on United States v. Alvarez-Machain, 68 NOTRE DAME L. REV. 723 (1993); Rosemary Rayfuse, International Abduction and the United States Supreme Court: The Law of the Jungle Reins, 42 INT'L. \& COMP. L. Q. 882 (1993);

51. See supra note 38.

52. See Alvarez-Machain, 504 U.S. at 663.

53. See supra note 24.

54. Alvarez-Machain, 504 U.S. at 663.

55. See Alvarez-Machain, 504 U.S. at 670 (stating that the case "involves a violation of the territorial integrity of that other country [i.e., Mexico], with which this country has signed an extradition treaty."); id. at 671 (concluding from a "fair reading of the treaty" and "applicable principles of international law" that the Supreme Court should have affirmed the decisions from the federal district and appellate courts).

The dissent continued:

It is true, as the Court notes, that there is no express promise by either party to refrain from forcible abductions in the territory of the other nation. Relying on that omission, the Court, in effect, concludes that the Treaty merely creates an optional method of obtaining jurisdiction over alleged offenders, and that the parties silently reserved the right to resort to self-help whenever they deem force more expeditious than legal process. If the United States, for example, thought it more expedient to torture or simply to execute a person rather than to attempt extradition, the options would be equally available because they, too, were not explicitly prohibited by the Treaty.

Id. at 674 (citations omitted); id. at 680-681 (citing to international legal scholars such as Oppenheim and Henkin as sources of international law and referring to the "rule against invading the territorial integrity of a treaty partner."); id. at 682 (calling the abduction a "flagrant violation of international law" and supporting this position with a note discussing customary international law). 
government, violated Mexico's sovereignty. Moreover, the United States committed a criminal act: kidnapping is prohibited under both U.S. and Mexican penal law. The Court demonstrated a general lack of awareness of and an attitude against the importance of international law in order to deliver an opinion that accorded with public policy and that condoned kidnapping. ${ }^{56}$

Lower court opinions illustrate similar disregard for international and regional law. The Eleventh Circuit once held that the President, acting directly or acting indirectly through his cabinet, has the power to "disregard international law in service of domestic needs[.]"57 Therefore, in the instant case, the Attomey General's controlling act- "termination of the status review plan and [the] decision to incarcerate [unadmitted Cuban aliens] indefinitely[,] pending efforts to deport"-could constitute "a sufficient basis for affirming the trial court's finding that international law does not control." In Sei Fujii v. California, the California Supreme Court discriminately struck down the California District Court's application of U.N. Charter provisions in an alien land discrimination case while simultaneously upholding the lower court's ruling:

[nothing in U.N. Charter] ... indicate[s] that these provisions were intended to become rules of law for the courts of this country upon the ratification of the Charter.

The language used in Articles 55 and 56 is not the type customarily employed in treaties which have been held to be self-executing and to create rights and duties in individuals....

[Articles 55 and 56] lack the mandatory quality and definiteness which would indicate an intent to create

56. Compare the recent opinion of the United Kingdom's House of Lords (that nation's highest court) over granting diplomatic immunity to General Pinochet of Chile: the majority, as well as the minority, looked heavily to many different sources of international law in reaching its holding that Pinochet should not be granted diplomatic immunity because actions like genocide, torture and hostage-taking are not within the range of normal activities for a head of state. Regina v. Bartle and the Commissioner of Police for the Metropolis and others, ex parte Pinochet (on appeal from a Divisional Court of the Queen's Bench Division); Regina v. Evans and another and the Commissioner of Police for the Metropolis and others, ex parte Pinochet (on appeal from a Divisional Court of the Queen's Bench Division). Text of decisionavailable gthttp://www.parliament.the-stationary-office.co.uk/pa/ld 199899//djudgmt/jd981 125/pino01. htmp.

57. Garcia-Mir v. Meese, 788 F.2d 1446, 1455 (11 th Cir. 1986), cert. denied, 479 U.S. 889 (1986).

58. Id. But see Richard Lillich, The United States Constitution and International Human Rights Law, 3 HARV. HuM. RTS. J. 53, 75 n. 150 (1990) (quoting Louis Henkin for the proposition that such a principle of serving domestic needs does not exist). 
justiciable rights in private persons immediately upon ratification. $^{59}$

The California Supreme Court completely ignored that the U.S. Constitution, through its Supremacy Clause in Article VI, does intend to make the provisions of the U.N. Charter "rules of law for the courts of this country upon the ratification of the Charter"60 just like any other treaty obligation in this country. Nevertheless, U.S. courts continue to follow Sei Fujii. ${ }^{61}$

This judicial immunity from international and regional law seems to have occurred only in the last fifty years when U.S. courts have had to witness the evolution of international and regional organizations and to face these institutions' growing legal authority. Consider the position of the Supreme Court at the turn of the last century: "International law is part of our law, and must be ascertained and administered by the courts of justice of appropriate jurisdiction ...." Ju2 Justice O'Connor recently spoke of the need for federal and state courts to return to this trend:

By negotiating and approving treaties and agreements which create transnational tribunals and prescribe their relationship with our domestic courts, the political branches of our government are asking the judiciary to not abstain from its usual adjudicatory function. They are ascribing a role for the courts in these specified areas of international relations. ... Just as state courts are expected to follow the dictates of the Constitution and federal statutes, I think domestic courts should faithfully recognize the obligations imposed by international law. ${ }^{63}$

That the current judiciary often refuses to uphold international and regional law in its decision-making indicates a lack of respect for the legitimacy of international and regional institutions and their laws that best serves public policy and the citizenry. Were teaching of worldism mandatory, the U.S. population would demand from their courts an interpretation of the law that properly incorporates these regional and international authorities.

59. Sei Fujii v. California, 242 P.2d 617, 621-22 (Cal. 1952).

60. Sei Fujii, 242 P.2d at 621.

61. See THOMAS BUERGENTHAL, INTERNATIONALHUMAN RIGHTS IN A NUTSHELL 312-315 (2d. ed. 1995).

62. The Paquete Habana, 175 U.S. 677, 700 (1900).

63. Sandra Day O'Connor, Federalism of Free Nations, 28 N.Y.U. J. INT'L. L. \& POL. 35, 40-42 (1995-96). 


\section{The Legislature}

In addition to examining the judiciary's recalcitrance, consider several recent activities in the United States Congress-arguably the most representative branch of government-where the words and deeds of its members reflect the current position of its constituents toward international legal obligations. The Senate has not ratified those international human rights agreements that the President, pursuant to Article II of the Constitution, has signed, thereby "maintaining [the U.S.] custom of generally leading multilateral efforts to draft international human rights instruments, and then allowing them to languish on the U.S. political agenda. 164

In November 1995, former Senator Bob Dole introduced the World Trade Organization ("WTO") Dispute Settlement Review Commission Act ${ }^{65}$ ("WTO Act") as part of the implementing legislation for the long awaited General Agreement on Tariffs and Trade ("GATT") completed in 1994. The WTO Act would have established a five-member panel of U.S. federal circuit judges ${ }^{66}$ to review decisions ${ }^{67}$ from the dispute.settlement panels ${ }^{68}$ and the Appellate Body ${ }^{69}$ to advise whether the United States would have to follow the decision; ${ }^{70}$ the panel would review such decisions only if the United States appeared as a defendant and the decision was adverse to the United States or the United States appeared as a complaining party and the United States Trade Representative requested the review. ${ }^{11}$ In essence, the WTO Act insured U.S. judicial sovereignty over a binding ruling from an international judicial body. The presumptiveness of the WTO Act would be tantamount to the New York state legislature's passage of a law granting to the New York Court of Appeals a right to review U.S. Supreme Court decisions that adversely impacted the State of New York in order to determine whether the State of New York really should follow such rulings. Although former Senator Dole's measure died in

64. James E. Dorsey, International Human Rights, 31 INT'L LAW. 659, 665 (1997). In addition to the human rights treaties mentioned infra, the list also includes the Convention on the Elimination of All Forms of Discrimination Against Women. (1995).

65. S. 1438, 104th Cong. (1995) The counterpart House bill was H.R. 1434, 104th Cong.

66. S. $1438, \S 3(\mathrm{~b})(1)$.

67. See Understanding on Rules and Procedures Governing the Settlement of Disputes (Understanding), Annex 2 to The Results of the Uruguay Round of Multilateral Trade Negotiations. The Legal Texts, G.A.T.T., 1994 (WTO Agreement), reprinted in ERNST-ULRICH PETERŚmANN, The G.A.T.T. / W.T.O. DisPUTE SETtlement SySTEM: INTERNATIONAl LaW, INTERNATIONAL ORGANIZATIONS AND DISPUTE SETTLEMENT, art. 19, at 319 (1997)[hereinafter Understanding]. Section 101 (d)(16) of the WTO Agreement makes the Understanding an "integral part of this [WTO] Agreement, binding on all Members." Id. at 177.

68. See id. art. 6, at 296-97.

69. See id. art. 17.1, at 303.

70. See S. 1438, § 4(a)(1).

71. See id. 
committee ${ }^{72}$ his and other Congressional members' comments at the time that he introduced the bill demonstrate the strong legislative commitment to protecting U.S. sovereignty. ${ }^{73}$

More recently, partisan politics over abortion and concern for the lack of accountability and administrative efficiency plaguing the U.N. Secretariat kept the House of Representatives from allocating sufficient funds to pay in full both U.S. membership dues and arrearages to the United Nations. ${ }^{74}$ Consequently, the United States remains in violation of Article 17(2) of the U.N. Charter and on the verge of losing its General Assembly vote. ${ }^{75}$ Yet, in a contractual sense, a U.S. promise to pay membership dues operates independently of the United Nation's promise to spend and operate with efficiency and accountability; instead of taking the unlawful step of withholding dues, the United States should take the lawful steps of using its Security Council veto power, General Assembly voting power, and general coalition building tactics to hold the Secretariat and other bodies more accountable and to streamline the spending practices of the organization and its specialized agencies.

Whether addressing human rights, international trade, or U.N. Charter obligations, Congressional reaction to the structure and laws of regional and international organizations echoes a voice from the average U.S. citizen who favors ignoring or, at least, weakening participation in and obligations from organizations and laws at the regional and international level.

\section{The Executive}

Like congressionally-initiated activity, executive branch efforts

72. See CCH Congressional Index 1995-1996 at 21 (concerning S. 1438) and 33 (concerning H.R. 1434).

73. See generally, Matthew Schaefer, National Review of WTO Dispute Settlement Reports: In the Name of Sovereignty or Enhanced WTO Rule Compliance, 11 ST. JoHN's J. LEGAL COMMENT. 307, $341-49$ (1996)(providing a brief history of the Dole Bill and its underlying theories).

74. See Foreign Affairs Reform and Restructuring Act of 1998 (Enrolled Bill), H.R. 1757, 105th Cong. (1998) ("Bill"). Although $\$ 2301$ of the Bill appropriated money (\$1 billion for fiscal year 1998; \$475 million for fiscal year 1999; \$244 million for fiscal year 2000) to the U.S. Department of State to pay almost all of the United States' membership dues and arrearages for the United Nations, its peacekeeping efforts, and its specialized agencies, President Clinton vetoed the Bill because $\$ 1816$, the result of a Republican Party-sponsored partisan amendment, prohibited the availability of such appropriations for any population assistance funds of any non-governmental organization, private organization, or multilateral organization (including the United Nations and its specialized agencies) that performed, counseled, or lobbied for abortions except in the case of rape, incest, or the endangerment of the life of the mother.

75. See Department of State, International Organizations and Peacekeeping, Hearings Before the Subcomm. on Depts' of Commerce, Justice, State and the Judiciary Appropriations of the House Comm. on Appropriations, 105th Cong. 307-361 (1998). 
demonstrate an attitude of isolationism and sovereignty protection. Since 1984, the United States remains dissociated from UNESCO ${ }^{76}$ despite that organization's subsequent correction of the grounds that the United States originally cited when it withdrew. ${ }^{77}$ The executive branch has not taken any steps to change this status.

In addition to its continued absence from UNESCO, the Clinton Administration recently decided to join China, Iran, Iraq, Israel, Libya and Yemen (and to break from the position of European and Canadian allies) in not signing the Rome Convention to establish a permanent United Nations International Criminal Court ("ICC") to adjudicate crimes against humanity (e.g., genocide, war crimes). ${ }^{78}$ After the executive branch reported this opposition vote to the Senate Foreign Relations Subcommittee on Operations in a July 1998 hearing, the Senate fervently proclaimed its opposition to the ICC, its support of U.S. sovereignty, and its commitment to block the ratification of the Convention by other nations. ${ }^{79}$ The executive and legislative branches primarily oppose the ICC out of concern that U.S. service

76. See The Activities of UNESCO Since the U.S. Withdrawal, U.S. Department of State Publication No. 9771 at 1-2 (1990); United Nations-Financial Issues and U.S. Arrears, General Accounting Office Publication No. NSIAD-98-201BR (1998) <http://www.access.gpo.gov/cgi-bin/getdoc.cgi?dbname= gao\&docid=f:ns9820l b.txt>.

77. See John E. Noyes ed., ThE UNITED NATIONS AT FIFTY: Proposals For IMPROVING ITS EFFECTIVENESS 134-41 (1997).

78. See Is a U. N. International Criminal Court in the U. S. National Interest?: Hearings Before the Subcomm. on International Operations, 105th Cong., 26-32 (statement of the Honorable David J. Scheffer, Ambassador-at-Large for War Crime Issues) (forthcoming 1999 for July 23, 1998 hearing) [hereinafter International Operations].

79. See id. at 7, where Senator Gramm states:

Now, we must affirm that the United States will not cede its sovereignty to an institution which claims to have the power to override the United States legal system and to pass judgment on our foreign policy actions. . . The only fail-safe way to ensure these results is to make sure that this treaty never is ratified by the 60 nations necessary for it to go into force. Should this court come into existence, we must have a firm policy of total non-cooperation, no funding, no acceptance of its jurisdiction, no acknowledgment of its rulings, and absolutely not referral of cases by the Security Council.

See id. at 16-17, where Senator Helms states:

[W] must ... I think be aggressively opposed to this court. ... So long as there is breath in me, the United States will never-and I repeat never, never-allow its national security decision to be judged by an international criminal court. ... It is an outrage that will have grave consequences for our bilateral relations with every one of the countries that signs and ratifies this treaty, and they better understand this at the outset.

See id. at 21-22, where Senator Ashcroft states:

The international criminal court in my judgment represents a clear and continuing threat to the national interests of the United States despite our decision not to participate. . . No aspect of the court is more troubling, though, than the fact that it has been framed without any apparent respect for and indeed in direct contravention of the United States Constitution. 
men and women and U.S. government decisionmakers would surrender substantial due process rights if tried for allegedly committing a crime against humanity before an international judicial body comprising, at least in part, foreign judges rather than before domestic civilian and military courts of solely U.S. judges. ${ }^{80}$ However, as questions and comments from the Senate hearing confirmed, the risk of an unfair or unjust trial before the ICC, let alone a trial at all, does not realistically exist. ${ }^{81}$ Overall, opposition to the formation of the ICC in order to protect U.S. sovereignty depicts international law and its institutions as an unknown "other" that is anathema to U.S. foreign policy and legal interests: ${ }^{82}$ such ignorance from present elected U.S. officials deepens the need for incorporating worldism into the schooling of future elected U.S. officials and future voter-constituents.

Finally, in the area of human rights, despite the Senate's recent adoption of the International Covenant on Civil and Political Rights ("ICCPR") and the U.S. Department of State's efforts to obtain ratification of the other international human rights instruments discussed above, the White House has not sought Senate confirmation on international and regional human rights instruments that grant U.S. citizens a right of individual petition against the U.S. government. Instead, the executive branch continues to protect the sovereignty of administrative and judicial legal decisions and to uphold the jurisprudence of the Eleventh Amendment. At the international level, the Optional Protocol to the ICCPR ("Optional Protocol") ${ }^{83}$ provides a right of

80. See id. at 7 (quoting Senator Gramm as stating, "We must refuse to allow our soldiers and Government officials to be exposed to trial for promoting the national security interests of the United States and deny the international court's self-declared right to investigate, prosecute, convict and punish U.S. citizens for supposed crimes committed on American soil which is arguably unconstitutional."); see id. at 15 (Senator Helms stating that "In short, this treaty represents a very real threat to our military personnel . ..."); see also id. at 22-23 (quoting Senator Ashcroft as stating that "First and foremost, I remain concerned by the possibility that Americans could be dragged before this court and denied the protection of the Bill of Rights....").

81. See id. at 41-42 (quoting Senator Feinstein as asking how realistic an unfair prosecution against an individual U.S. soldier or the United States would be in light of all of the Rome Convention's safeguards); see id. (quoting Professor Scharf as explaining that five levels of protection exist against politically frivolous suits brought in the I.C.C. against the United States or any of its government or military personnel).

82. See id. at 2-3 (quoting Senator Gramm as stating that "[T] he proposed I.C.C. is not part of the international system. It sits alone and above the system, and that is by design ...."); see id. at 14 (quoting Senator Helms as stating that "the Rome treaty is irreparably flawed."); see id. at 21 (quoting Senator Ashcroft as stating that "[ $t]$ he international criminal court in my judgment represents a clear and continuing threat to the national security interest of the United States despite our decision not to participare.").

83. International Covenant on Civil and Political Rights, December 16, 1966, Optional Protocol, 999 U.N.T.S. 171(1967), reprinted in SELECTED DOCUMENTS, supra note 13, at 373 [hereinafter Optional Protocol]. 
individual petition for guarantees in the ICCPR ${ }^{84}$ Although the United States recently ratified the ICCPR, the United States is not a party to the Optional Protocol. At the regional level, Article 44 of the American Convention on Human Rights ("American Convention") provides a similar right of individual petition at the regional level by allowing "[a]ny person or group of persons, or any nongovernmental entity legally recognized in one or more member states of the Organization [of American States], [to] . . lodge petitions with the [Inter-American] Commission containing denunciations or complaints of violation of this [American] Convention by a State Party"85 and, ultimately, to receive a decision from the Inter-American Court of Human Rights. As with the Optional Protocol, the United States is not a party to the American Convention. ${ }^{86}$

Given the conclusions from the Buergenthal and Torney study, resistance and inactivity on the part of the courthouses, the Capitol, and the Cabinet merely replay the general lack of respect for the legitimacy of the history, structure, and laws of international and regional organizations among the U.S. population. Mandatory teaching of worldism at the primary and secondary school levels is the key to changing this status quo: "[W]e are presently educating children who will, by their actions as adult citizens ... determine the shapes of law and the administration of justice, social and political institutions, and whether a state of war or peace will prevail."87 With that much potential power, children today must receive more formal instruction in worldism than U.S. state curriculum statutes currently mandate.

\section{What Changes to U.S. Education LAWS NEED TO OCCUR?}

If the United States accepts the premise that primary and secondary schools should teach worldism, then the responsibility for change rests primarily with three parties: U.S. state legislatures need to change curriculum statutes; U.S. state education departments need to promulgate new rules and regulations to implement such changed statutes; and local school boards need to develop the details of such curricula and oversee their administration. Efforts must start at the legislative level because statutory mandates are the only effective way to guarantee that schools adequately teach worldism,

84. International Covenant on Civil and Political Rights, December 16, 1966, 999 U.N.T.S. 171, reprinted in SELECTED DOCUMENTS, supra note 13, at 357.

85. American Convention on Human Rights, November 22, 1969, art. 44, 9 I.L.M. 673 (1970), reprinted in SELECTED DOCUMENTS, supra note 13, at 463; see also arts. 34-51, supra note 13, at 461-466 (regarding the Inter-American Commission of Human Rights)[hereinafter American Convention].

86. See id. at 451 .

87. BUERGENTHAL \& TORNEY, supra note 41 , at 115 . Although the quote referted to children of the 1980 s, the conclusion remains true today. 
properly train teachers, and sufficiently allocate their federal, state, and local funds. "Without adequate funding, piecemeal low budget efforts are likely to continue for the forseeable future similar to the type of efforts pursued in the past." ${ }^{\text {88 }}$ Although non-profit education organizations in the United States aim to increase worldism teaching efforts, they have not yet focused on lobbying for legislative change. ${ }^{89}$

Current curriculum statutes, regulations, and standards in each of the fifty states, territories, and abroad (i.e., U.S. Department of Defense schools) do not require schools to cover worldism for a child to complete primary and secondary school..$^{90}$ Local school boards, administrators and teachers often incorporate aspects of the United Nations, multilateralism, and human rights into world history and post-Cold War studies courses. ${ }^{91}$ However, the only

88. Smith, supra note 47 , at 17.

89. Recent efforts undertaken by the National Council on Social Studies, the Council of Chief State School Officers, the Stanford Program on International and Cross-Cultural Education, and other similar non-profits include: (1) encompassing primary as well as secondary schools; (2) drafting standards; (3) educating teachers; (4) establishing state level international studies center; (5) obtaining state level legislative support; and (6) expanding in the direction of telecommunication. Paul Haakenson, Recent Trends in Global/International Education, ERIC DIGEST 1 (1994). Even with all of these positive developments, none lobbies for legislative change to make worldism a required course. Moreover, the global and international education that these efforts envision fall short of the depth and breadth of federal, state, and local civics classes:

For over 25 years, the field of global/international education has attempted to develop a rationale and resources to support educators who make explorations of the world and its peoples a part of their curriculum. Many educators have written that in order to be fully prepared for the complexities of the 21 st century, young people should be imbued with a global perspective. Attaining this world view may involve several approaches, including the study of cultures, languages, international issues, responsible citizenship in an interdependent world, and global connections within local communities.

Id.

90. Although not yet incorporated into the Wisconsin statutes as a mandated class, the social studies performance standards for political science and citizenship from the Wisconsin Department of Public Instruction include components of worldism. See State of Wisconsin Dept. of Public Instruction-Wisconsin Model AcademicStandards <http://www. dpi.state. wi.us/

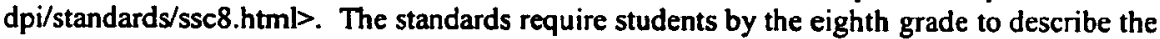
role of international organizations such as military alliances and trade associations and require students by the twelfth grade to explain the United States role in intemational organizations such as the United Nations, North American Treaty Alliance, the World Bank, the International Monetary Fund, and the North American Free Trade Agreement. See id.

91. See Susan Graseck, Teaching Foreign Policy in the Post-Cold War Era, ERIC DIGEST (1993) (discussing the need for U.S. students to develop an understanding of the issues shaping intemational relations); John Douglas Hoge \& Rodney F. Allen, Teaching About Our World Community: Guidelines and Resources, in SOCIAL STUDIES AND THE YOUNG LEARNER (1991)(discussing how to teach students about other cultures and countries); John J. Patrick, Global Trends in Civic Education for Democracy, ERIC DIGEST (1997) (discussing how " $[t]$ eachers are requiring students to compare institutions of constitutional democracy in their own country with insitutions in other democracies of the contemporary world ... [in an effort] 
components of social studies curricula that state statutes actually require include (1) the history of the United States and, often, the history of the student's state of residence; (2) the organization of the United States government and, often, the organization of the student's state government, local government, or both; and (3) aspects of civil and criminal law at the federal, state, and local levels. ${ }^{92}$ The absence of required classes concerning worldism sends a message to children, parents, teachers, and the community that the history, structure, and laws of international and regional organizations simply are not as important or as legitimate as the history, structure, and laws of federal, state, and local organizations. Unless students elect to enroll in a course on the subject or one of their teachers opts to cover aspects of worldism, those students may graduate high school not knowing that the U.N. and the OAS exist, and not understanding the concepts of a treaty or a resolution. Lacking such a background by the time one becomes a voting citizen and working adult affects the ability of this nation as a whole to advance the cause of international law, develop the efficiency of international and regional organizations, and know the advantages in citizens' daily lives for having done so. ${ }^{93}$

Recent changes to education statutes in the states of Florida, Nebraska, and California to require aspects of multiculturalism in social studies curricula provide a model for similar statutory changes that might be made to mandate worldism. Florida statutes, entitled "Required instruction", set forth mandatory curriculum requirements for all Florida public schools. ${ }^{94}$ In 1994, the legislature supplemented the statutes to incorporate teaching about the Holocaust ${ }^{95}$ and about the history of African-Americans in the United States and the State of Florida before, during, and after slavery. ${ }^{96}$ In 1998, the legislature added subsections to incorporate, respectively, the study of the contributions of Hispanics ${ }^{97}$ and the contributions of women ${ }^{98}$ to the history of the United States.

The State of Nebraska added five statutes in 1992 to provide for multicultural education in its schools. The first provision defines multicultural education. ${ }^{99}$ The second requires the development and

to diminish ethnocentrism."). December 20, 1999 Efforts discussed in these position papers do not fully encompass teaching about international and regional institutions--their history, structure, and laws-but focus instead on nation-states in the global community, whether the United States or another country.

92. See statutory provisions cited supra note 9.

93. See supra text accompanying notes 30 and 31 .

94. FLA. STAT. ANN. \$233.061 (West 1998),

95. 1994 Fla. Sess. Law Serv., ch. 94-114, \$1 (West).

96. 1994 Fla. Sess. Law Serv., ch. 94-225, \$ (West).

97. $1998 \mathrm{Fla}$. Sess. Law Serv., ch. 98-229, \$1 (West).

98. 1998 Fla. Sess. Law Serv., ch. 98-421, § 2 (West).

99. Neb. REV. Stat. § 79-719 (1996). 
incorporation of multicultural education into the curriculum of kindergarten through twelfth grade (K-12) ${ }^{100}$ The third statute sets forth the duty of school districts to provide evidence of such development and incorporation in order to retain accreditation status. ${ }^{101}$ The fourth provision prescribes that the State Department of Education design a process to evaluate the implementation and effectiveness of each multicultural education program. ${ }^{102}$ Finally, the fifth statute authorizes the State Department of Education to adopt and promulgate rules and regulations to carry out the new statutory provisions. ${ }^{103}$ In addition to legislative changes, the Nebraska Department of Education passed rules, effective October 11, 1993, implementing the legislature's new multicultural education program. ${ }^{104}$ Today, Nebraska students in grades $\mathrm{K}-12$ complete one multicultural education component for each year of study.

Providing a third example, the State of California amended the social studies curriculum of its education laws to include aspects of multiculturalism. ${ }^{105}$ In 1992, the legislature expanded the human rights component of the seventh through twelfth grade social studies curriculum to include explicitly the study of U.S. slavery and the Holocaust. ${ }^{106}$ In 1993, the

100. NeB. REV. StaT. § 79-720 (1996).

101. NeB. ReV. STAT. § 79-721 (1996).

102. NEB. REV. STAT. § 79-722 (1996).

103. NEB. REV. STAT. § 79-723 (1996).

104. NEB. ADMIN. R. \& REGS., tit. 92, c. 16.

105. For grades one to six the curriculum covers six subjects: the history, resources, development, and government of California and the United States; the development of the American economic system; the relations of persons to the natural environment; eastern and western cultures; human rights issues; and use of natural resources. CAL. EDUC. CODE $\S$ $51210(c)$ (West 1998). For grades seven to twelve, the curriculum also covers six subjects: the history, resources, development, and government of California and the United States; the American legal system, the juvenile and adult criminal justice systems, and the rights and duties of citizens under civil and criminal law and the state and federal constitutions; the development of the American economic system; the relations of persons to the natural environment; eastern and western cultures; and human rights issues, particularly genocide, slavery, the Holocaust and contemporary issues. CAL. EDUC. CODE $\$ 51220$ (b) (West 1998). Moreover, to graduate from high school, the state requires at a minimum the completion of three social studies courses that cover (1) the history and geography of the United States, (2) the history, culture and geography of the world, (3) the government and civics of the United States and (4) economics. CAL. EDUC. CODE $§ 51225.3(\mathrm{a})(1)(\mathrm{D})$ (West 1998).

106. Section 1 of Assembly Bill No. 3216 (1991-1992 Regular Session) amended Section S1220(b) of the Education Code to read "human rights issues, with particular attention to the study of the inhumanity of genocide, slavery, and the Holocaust, and contemporary issues" and added Section 51226.3 in its entirety in order to detail curriculum frameworks primarily at the high school level that would cover these new areas. As evidence of the legislature's intent for changing the law, the Legislative Counsel's Digest states:

Existing law prescribes the adopted course of study for grades 7 to 12 , inclusive, including a course in social sciences that is required to include instruction in human rights issues.

This bill would require that this instruction include study of slavery and the Holocaust, thereby imposing a state-mandated local program. 
legislature changed the wording of the social studies curriculum component concerning the environment from gender specific to gender neutral, which, in effect, resulted in the addition of women's studies to the curriculum. ${ }^{107}$

\section{CONCLUSION}

Just as history classes need multiculturalism to provide students with an accurate telling of the past, so government classes need worldism to provide students with an accurate telling of the present as well as the future.

International law is law like other law, promoting order, guiding, restraining, regulating behavior. States, the principal addressees of international law, treat it as law, consider themselves bound by it, attend to it with a sense of legal obligation and with concern for the consequences of violation. Some states refer to international law in their constitutions; many incorporate it into their domestic legal systems; all take account of it in their governmental institutional arrangements and in their international relations. ${ }^{108}$

Despite this statement, the enforceability of the international legal system remains "in a rough and rudimentary form"109 in contrast to the enforceability of U.S. federal, state and local law. For the most part, U.S. citizens and their governing bodies do not show the same respect for the legitimacy of international law and its institutions as for the legitimacy of domestic law and its institutions.

This Article has demonstrated not only that a change in attitude must

This bill also would require the State Department of Education to incorporate, into publications that provide examples of curriculum resources for teacher use, those materials developed by private sources that are age-appropriate and consistent with the subject frameworks on history and social science that deal with human rights violations, genocide, slavery, and the Holocaust.

CAl. EduC. CODE $\S 51226.3$ (West 1998).

The bill went through three amendments since its February 20, 1992 introduction. The first two occurred in the Assembly on April 6,1992 and May 11, 1992 and focused only on genocide and the Holocaust; the third took place in the Senate on August 17, 1992 and added slavery to the expanded human rights list. Id.

107. Section 47 of Assembly Bill 2211 (1992-1993 Regular Session) changed "man's relations to his human and natural environment" to "the relationship of humans to their natural environment," thus ensuring that women's relations as well as men's relations would be studied.

108. RESTATEMENT (THIRD), supra note 24 , at 17.

109. Fitzmaurice, The Foundations of the Authority of International Law and the Problem of Enforcement, 19 M.L.R. 1 (1956), cited in D.J. HARRIS, CaSES aND MATERIALS of INTERNATIONAL LAW 6 (3d ed. 1983). 
occur, but that to be most effective, such change must originate with the social studies curriculum statutes that govern U.S. schools throughout the fifty states and overseas. The teaching of worldism-that is, the history, structure, and law of international and regional institutions-in the educational institutions of this country cannot be limited to merely a specialization for lawyers and law students, a concentration for undergraduate and graduate students or an elective for high school seniors. It must become part of the basic primary and secondary school curriculum in order to raise awareness among the general U.S. population to a level that will tolerate, permit, and hopefully even demand the strengthening of international and regional law at the domestic level. Such strengthening will ready the United States for the global realities of the new millennium. 